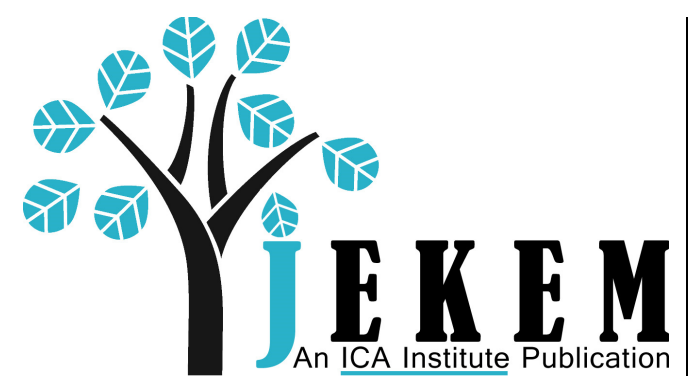

India, China ANd America Institute

1549 CLAIRMONT ROAD, SUITE 202 • DECATUR, GA 30033 USA

WWW.ICAINSTITUTE.ORG

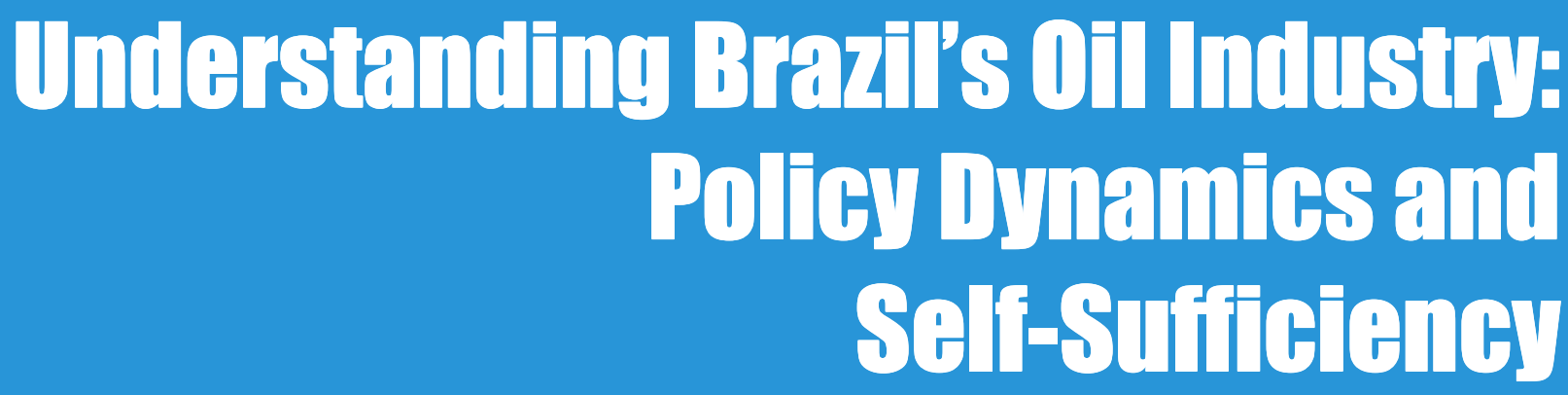

Erjia Joy Guan

Journal of Emerging Knowledge on Emerging Markets

Volume 2

November 2010 


\section{Understanding Brazil's Oil Industry: Policy Dynamics and Self-Sufficiency}

Erjia Joy Guan

Florida International University

Journal of Emerging Knowledge on Emerging Markets Volume 2

November 2010

$\mathrm{T}$ The oil industry in Brazil has progressed from the dream for self-sufficiency in oil begun in the 1930s to the country's attainment of that vision in 2006. During this period, Brazil has experienced not only changes in government leadership differing in political priorities, but also diverse forms of political leadership, to include democracy, military junta, and dictatorship. This paper focuses on the premise that despite changes in the type of Brazil's governmental leadership - and their respective political priorities and economic policies - the nation has engaged in a continual movement toward the fulfillment of the vision of self-sufficiency in oil. It has achieved this goal through a relatively consistent and self-adjusting set of policies and practices. In this paper, "continual" is operationally defined, as it is in the Shorter Oxford English Dictionary (Stevenson, 2007, p. 505), as "forming a connected whole" and "perpetually existing or acting." Thus, it is posited that the adherence to its self-sufficiency-in-oil vision by seemingly competitive, if not conflictive, leadership models has resulted in the progressive development of Brazil's oil industry, and in turn, its economy. For the purposes of this paper, economic development will be measured by GDP growth rate (See Appendix A, Figure A1). The development of the oil industry will be measured by crude oil production in barrels per day (bpd) and domestic production's share of national consumption (See Appendix B, Figure $\mathrm{B} 1$ and B2).

Estimates of recent offshore oil discoveries since 2007 place Brazil among the world's top ten countries in oil reserves. In light of these estimates, the government is considering a 


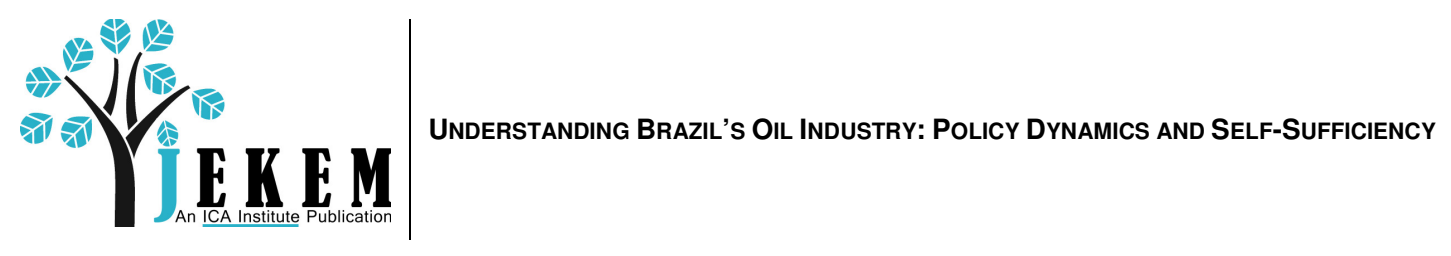

new legal framework comprised of three controversial features: (1) production sharing and concessions for exploration and production in the territory, (2) creation of Petro-Sal to represent the government's interests in negotiations of contracts, and (3) allocation of government revenues from this area for social development. This paper will assess the implications of the new framework in relation to continuing the country's historical goal and achievement of self-sufficiency in oil.

\section{Conditions Leading to the Oil Self-Sufficiency Vision of 1938}

By the end of World War I in 1918, governments and companies around the world, including Brazil, had realized the potential significance of oil for energy production and as an essential input to industrial development. Brazil's dependence on imports of crude oil to fuel transportation of goods and as an energy source for industrial development and economic growth contributed to an increasing foreign debt. The Brazilian elite and traditional business interests supported President de Sousa's government (1926-1930), which prioritized foreign investment and trade as the primary engines of growth (Hudson, 1997). Brazil relied primarily on oil to fuel its growing industries, and the country's oil policy consisted of granting concessions to private, mostly foreign, investors. Several foreign oil companies dominated Brazil's refineries and distribution, but were unsuccessful in discovering oil (Wilkins, 1973). Thus, the government recognized the issues associated with the country's dependence on oil imports, namely their inability to control fluctuations in prices or stability of supply, which caused not only economic concerns, but also one of national security. This set of concerns formed the foundation for the inception of the selfsufficiency-in-oil vision.

\section{The Vargas Era as a Critical Path toward a Common Oil Self-Sufficiency Vision}

The Stock Market Crash of 1929 and the onset of the Great Depression had dramatic effects on Brazil's economy, as its coffee and other exports plummeted and the government soon depleted the country's gold reserves (Hudson, 1997). Following the government's bankruptcy and national social unrest, Dr. Getúlio Dornelles Vargas was placed in power (1930-1945) by a military coup on November 3, 1930 for what resulted in a 15-year reign (Bethell, 2008; Hudson, 1997). Vargas maintained power by granting the opposition protection of their interests and drafting a new Constitution in 1934 that included electoral reforms; Vargas also declared the "Estado Novo" or "New State" in 1937, thus becoming dictator of Brazil (Bethell, 2008; Hudson, 1997). After dissolving Congress and political parties, Vargas sought to advance Brazil's industries by intensifying investment and control by the government, particularly to create a domestic oil industry.

In 1938, in response to slow development of the oil industry by foreign firms and growing national security concerns over oil, Vargas created the "Conselho Nacional do Petróleo," the National Petroleum Council (CNP), which was given broad, but not monopoly powers, 
and operated alongside foreign oil companies (Randall, 1993; Smith, 1972; Surrey, 1987). With Army General Staff J. C. Horta Barbosa as CNP President, its operations discovered oil a year later, in 1939, giving the Brazilian people great pride in the CNP, and, by extension, in the government, particularly as foreign oil companies had previously failed to find oil in Brazil (Smith, 1972). The start of World War II in 1939, coupled with fears of oil shortages experienced in World War I, contributed to proposals in the early 1940s by foreign oil companies for partnerships. However, the government leadership respected the CNP's broad powers as Barbosa rejected tempting requests for partnerships by foreign oil companies on "grounds of national security" (Smith, 1972, p. 184). Although the CNP's drilling program continued to discover more oil in the 1940s, daily CNP production met less than 10\% of consumption needs in 1942 (Surrey, 1987; Wirth, 1970). Throughout the 1930s, Brazilian industry expanded $11.2 \%$ on average per year; and over the fifteen years of the Vargas reign (1930-1945), GDP increased at an average annual rate of 4\% (Hudson, 1997).

After the end of WWII in 1945, the military deposed Vargas through another coup, and President Eurico Gaspar Dutra, a military leader, was elected to a four-year term (19461950). The government took measures to lift restrictions on foreign investment in the oil industry, believing it would increase efficiency of oil output. The Constitution of 1946 opened the oil sector to foreign companies' subsidiaries in Brazil and later the government instituted the SALTE Plan (Law 1,102), a public expenditure program for the years 1950 to 1954, which called for $17.8 \%$ of proposed funding to aid in development of energy sources, particularly petroleum, in an effort to decrease the country's dependency on its imports (Wythe, 1949). The effects of these measures, along with a sharp drop in exports and rising imports, caused the balance of payments deficit to increase. Brazil's total external debt, including foreign investment in the oil industry, from 1947-1951 was $\$ 590$ million, equaling $5.2 \%$ of its GDP and $47 \%$ of its total export value (Tyler, 1981).

In response to the new Constitution's favorable measures for foreign investment, coupled with the lack of progress in oil exploration and domestic production by the foreign oil companies, the political opposition began, in 1947, to spread the nationalist message of its campaign platform: "O Petróleo é nosso," "the oil is ours." This group, the economic nationalists, believed Brazil's need to industrialize and become independent of oil imports necessitated government control over the oil industry, and the exclusion of foreign companies in it (Smith, 1972). The campaign of 1947 sought government intervention in the oil industry and to ensure Brazilians, not foreigners, would receive the benefits that the industry was widely anticipated to provide in the near future (Smith, 1972). This movement coincided with the dawn of a critical mass in the populous that favored implementation of the vision of self-sufficiency in oil; consequently, the campaign became widely successful, "galvanizing mass opinion behind [a] state monopoly," that later affected Congress in their deliberations of prospective changes in the oil industry (Smith, 1972, p. 185; Wirth, 1970). 


\section{Government Action toward Vision Implementation}

By the late 1940s, the Brazilian government and people recognized the inefficiency of efforts to develop its oil industry, even with foreign oil interests involved, as well as the country's continued dependence on oil imports. After being elected President a second time, Vargas (1951-1954) submitted a bill to Congress in 1951 to create a state-owned oil company and, echoing the 1930s military dictum, decreed in 1952 that "oil was part of national security" (Randall, 1993, p. 10; Smith, 1972). After political tensions abated and significant changes made to the proposal, on October 3, 1953, Brazil's government created Petróleo Brasiliero, S.A. (Petrobras) through Law 2,004 (De Sa Ribeiro, 2001; Gledhill, 2008; Petrobras, 2008a; Smith, 1972). The government's vision in creating Petrobras was one of a fully integrated company that would eventually make the country self-sufficient in oil (Petrobras, 2008a). The government granted Petrobras monopoly power in all sectors of the oil industry, other than wholesale distribution and retail, prohibited foreign investment in the company, and CNP retained regulatory powers over the oil industry (Petrobras, 2008; Randall, 1993). During its first year, Petrobras produced less than 2,700 barrels per day (bpd), not quite $3 \%$ of national consumption, and had proven recoverable reserves of 15 million barrels (Petrobras, 2008a).

\section{Effects of Government Priorities on the Vision of Self-Sufficiency in Oil}

In pursuit of Brazil's persistent plans for industrial development, President Juscelino Kubitschek (1956-1961) implemented a large-scale development plan, aiming to achieve "Fifty years' progress in five" in six critical sectors, including investing heavily in development of the energy sector (Bello, 1966; Hudson, 1997, p. 74). As a result, Petrobras' production increased dramatically to over 80,000 bpd in 1960 , achieving nearly $30 \%$ of Brazil's consumption needs, a clear indication that the company was markedly on its way to reaching the national vision of self-sufficiency (EIA, 2009; Petrobras, 2008a). From 1956 to 1960 , Brazil's GDP also grew steadily at an average annual rate of $6.9 \%$, spurred on by substantial gains in industrial development, which grew at an annual rate of $10.1 \%$. Petrobras soon became a symbol of "national liberation from 'colonial imperialism' and dependence on foreign capital" to the Brazilian people (Raine, 1974, p. 144). This popular support for Petrobras caused politicians to increasingly use the company as a political symbol and political struggles for control over the company began to produce various negative effects. In particular, a high turnover rate in leadership (as Petrobras' president was appointed by Brazil's President) resulted in ineffectual decision-making, company instability, and would eventually lead to stagnation in drilling and output (Petrobras, 2008a; Smith, 1972).

Until 1960, the average annual rate of inflation had been $20.6 \%$ for the previous four years, making imports more expensive and decreasing the buying power of much needed industrial inputs, such as oil (See Appendix A, Figure 2). Export values were beginning to 
trail those of import, and the country's external debt had increased to 14.5\% of GDP in 1961 (Tyler, 1981). By the end of Kubitschek's presidential term in 1961, the industrial sector accounted for more than 30\% of GDP, from only $23.5 \%$ in 1950, but at the cost of heavy government debts that amounted to over $\$ 2$ billion (Hudson, 1997; Tyler, 1981). President João Goulart (1961-1964) entered office facing profound national issues of vast foreign debts, soaring inflation and currency depreciation, and a widening deficit in the country's balance of payments (Hudson, 1997). Goulart's administration failed to successfully address these problems and political unrest, riots, and strikes by unions, including the union of oil workers, spread throughout the nation. The energy sector was affected by decreasing output; however, the debilitating political environment was mitigated by low global prices for oil and the government's delegation of monopoly powers over imports of crude oil to Petrobras in 1963. This period of destabilization had negative impacts on the vision of self-sufficiency in oil, as it caused decreased exploration and production along with decreasing reserves estimates.

\section{Self-Adjustment: The Effect of Shift on Adherence to Vision of Self-Sufficiency in Oil}

The people of Brazil disapproved of the government's inability to tackle the national financial problems under the leadership of President Goulart. Thus, the military carried out another successful coup d'état with the motto "development with security" in 1964 (Randall 1993, p. 263). The regime under President Branco (1964-1967) worked to stabilize the country by lowering inflation through a crawling peg exchange rate, balancing the budget, and developing Brazil into a modern, industrialized powerhouse (Hudson 1997, Leacock 1990). The government increased fiscal incentives to exporters, expanded state enterprises, and provided increased opportunities for foreign investment by liberalizing the financial markets (Tyler 1981). Petrobras received further government investment and continual leadership as it was expected to provide energy sources for industrial development (Leacock, 1990). As a result of the government's prioritization of the oil sector, Petrobras attained a three-fold gain in production in less than ten years, increasing refining capacity from 325,000 bpd in 1964 to over 1 million bpd in 1973 (Randall, 1993). In 1967, Petrobras made its first offshore oil discovery in Sergipe and in 1969, the government determined that $5 \%$ of future offshore oil revenue would remain with the federal government, instead of the states, thus differing from the policy relative to onshore revenues (Raine, 1974). Petrobras also reached self-sufficiency in the sectors of transportation and refining in 1970, and raised its share of distribution (Surrey, 1987). From 1968 to 1974, the government's economic policies induced substantial export growth, from $\$ 1.8$ billion to $\$ 8.5$ billion and increased savings - both domestic and foreign-while GDP grew at an average rate of $11 \%$ (Tyler, 1981). 
Guan: Understanding Brazil's Oil Industry: Policy Dynamics and Self-Sufficiency

Understanding BraziL’s OIL Industry: Policy Dynamics and Self-Sufficiency

\section{Effects of External Factors on Brazil's Vision of Self-Sufficiency in Oil}

Despite economic growth from 1964-1974, political instability mounted due to the repressive military regime. The international oil crisis of 1973-1974, which induced a sharp rise in global oil prices and caused oil imports to increase from \$606 million in 1973 to \$2.6 billion in 1974, helped the regime justify Petrobras' monopoly powers to the people of Brazil (Raine, 1974; Surrey, 1987). President Ernesto Geisel (1974-1979), a General and former President of Petrobras, once again made self-sufficiency in oil a priority for the government in order to shield the economy from further price shocks like those of 19731974. Brazil's energy policy prioritized increasing exploration and production of oil along with government investment in alternative energy sources, such as ethanol (Randall, 1993; Tyler, 1981). In 1975, the government began allowing foreign companies to explore for petroleum within Brazil under risk contracts in order to speed up exploration and production efforts. These risk contracts opened Brazilian oil exploration to foreign investment and technology, and investors received a share of oil or cash equivalent if the exploration effort proved successful (Randall, 1993). Partly as a result of the increased exploration efforts caused by the spike in oil prices in 1973, Petrobras discovered the first field in the Campos Basin in 1974, which had proven reserves of 1.4 billion barrels (Petrobras, 2008a; Randall, 1993). Industrial output also increased from 24\% of GDP in 1950 to $38 \%$ in 1979 (Tyler, 1981). The increased funding and government attention to oil exploration, production, and refining helped Petrobras fortify its competitive strength, and the oil shock of 1979 , which increased oil prices from $\$ 12$ to $\$ 34$ per barrel, further reinforced the government's actions toward achieving self-sufficiency in oil as quickly as possible.

In 1975, attempting to limit national oil consumption, the government began the Proálcool program, a subsidization program for ethanol to reduce oil imports, and by extension, the economy's susceptibility to fluctuations in oil prices (Hudson, 1997; The World Bank, 1978). Brazil's ethanol, also known as fuel alcohol, is made from sugar cane, initially blended with gasoline for commercial use. The government inflated fuel prices in order to subsidize the ethanol program and set the price of fuel alcohol at around $35 \%$ that of gasoline (Surrey, 1987; Randall, 1993). Through these policies, the government returned to its previous policy of prioritizing the oil industry in a marked effort to attain the goal of self-sufficiency in oil. During this period, Petrobras began to acquire expertise in undersea exploration and production, and had substantially increased its production, from 165,000 bpd in 1979 to 546,000 bpd in 1985 (Global Agenda, 2009; Petrobras, 2008a). Petrobras' refining capacity did not rise due to increasing ethanol substitution for gasoline consumption, which totaled to over half of fuel consumption for cars in 1985 (Surrey, 1987). In 1985, after a period of political transition, José Sarney (1985-1990) was inaugurated and the government gave royalties to states and municipalities from offshore drilling that had been previously reserved for the federal government and created a special fund for distribution of oil revenues throughout the country. 


\section{A New Approach to Reaching the Vision of Self-Sufficiency in Oil}

Sarney's inauguration in 1985 marked the end of the military regime, curbed political instability, and eventually led to the Constitution of 1988. The civilian government, under the new constitution, gave priority to social reforms while maintaining the state's role in the economy (Hudson, 1997). With regard to Petrobras, the Constitution of 1988 prohibited future risk contracts due to their perceived inconsistency with monopoly rights of Petrobras (Oil \& Gas Journal, 1991; Randall, 1993). By 1989, Petrobras produced half of national oil consumption and had total proven reserves of over 47 million barrels of crude oil and natural gas liquids (NGL) (Petrobras, 2008a; Randall, 1993; World Development Indicators, 2010). Petrobras had also reduced dependence on foreign capital inputs and purchased over $90 \%$ of its equipment and materials from Brazilian suppliers (Furtado, 2002).

Despite its myriad attempts to tackle the problems of Brazil's debt and inflation, the government was unable to control the currency and public finances. In 1990, inflation reached over 2,000\% while GDP decreased 4.3\% (World Development Indicators, 2010). In 1993, President Franco (1992-1994) appointed Fernando Henrique Cardoso as the Minister of Finance when inflation had once again reached astronomical levels (World Development Indicators, 2010). Cardoso's "Real Plan," implemented in 1994 was a fiscal and monetary plan that began with a balanced budget for government spending, then indexed prices, and ended with the implementation of Brazil's new currency, the Real (Hudson, 1997). The "Real Plan" effectively stabilized the economy and by December 1994, inflation was less than $1 \%$ and, in 1995, GDP had grown to 4.4\% (World Development Indicators, 2010). As a result, the people elected Cardoso (1995-2003) President the following year.

President Cardoso's vision for Brazil's growth and development was to liberalize the economy through privatization, utilizing the National Privatization Program (PND), and economic deregulation, which included ending state monopolies (de Noronha Goyos, 2003; Gledhill, 2008). In 1995, Congress passed amendments to the Constitution of 1988, that ended Petrobras' monopoly, and Law 8,987, the "Concessions Law," which allowed the private sector to bid for concessions formerly held solely by the state (de Albuquerque Barreto, 1998; de Noronha Goyos, 2003). Petrobras became a public corporation, of which the state continued to own $51 \%$ of shares, and retained a substantial share of the Brazilian oil market (Gledhill, 2008; Petrobras, 2008a). Brazil experienced growth in its GDP coupled with substantially reduced inflation, which was $7.6 \%$ by 1997 (World Development Indicators, 2010). In 1997, the privatization wave continued with Law 9,478, commonly referred to as the "Petroleum Law" or the "Oil Law," by which the government eliminated subsidies, import and price controls in the oil industry, and introduced competition in exploration, production, refining, and distribution of petroleum. This law also created the National Petroleum Agency (ANP), a regulatory body, to promote competition and attract foreign investments in the petroleum sector (De Albuquerque Barreto, 1998; De Noronha Goyos, 2003). The ANP held the first annual bidding rounds for onshore and offshore oil blocks on June 15-16, 1999, resulting in the award of 12 blocks to 11 companies (including 
Petrobras, BP, Shell, and Texaco), representing 6 countries (ANP, 1999; The Economist, 2002).

Though Petrobras was no longer a state monopoly under the Constitution, the company continued to dominate private oil firms' exploration efforts for oil in Brazil (Gledhill, 2008; Petrobras, 2008a; Schneyer, 2007). During this period of transition, Petrobras faced political and economic pressures in the face of rising fuel costs, developing technology in biofuels, and advancing its deep-water drilling technology (Global Agenda, 2009). In 1997, Petrobras produced almost 850,000 bpd of crude oil and over 1.3 million bpd of refined products, and achieved profits of $\$ 1.373$ billion (Foreign Affairs, 2009; Petrobras, 2008a). The elected government's new approach, through privatization and deregulation, seemed to have contradicted the vision for attaining self-sufficiency in oil by eliminating Petrobras' monopoly (Zybersztajn, 1998). However, the policies in effect advanced the vision of selfsufficiency of oil in Brazil since Petrobras needed to increase competitiveness and efficiency to face competition in the oil market.

In 1998, investor anxiety spread from financial crises in other developing economies and Brazil, unable to retain the Real's peg to the Dollar, entered its own financial crisis in 1999 (Gruben \& Kiser, 1999). Though the crisis did not affect Petrobras' crude oil production, which surpassed 1 million bpd in 1999, the company's gross operating revenue decreased by $11 \%$ and net income decreased 15\% (Petrobras Annual Report, 1999). In 2000, Petrobras reported a net income of $\$ 5.3$ billion, up from $\$ 727$ million in 1999 , generated partly by a $60 \%$ increase in global oil prices (Petrobras Annual Report, 2000). By 2001, Brazil was the world's eighth largest economy, with exports of $\$ 58$ billion that comprised approximately $10 \%$ of GDP (Hakim, 2002). In January 2002, the government completed the privatization of the oil industry by abolishing government control over energy prices and ending Petrobras' monopoly over oil imports (The Economist, 2002). Shortly after, fuel costs began to rise and contributed to an increase of over 8\% in inflation in April 2002 (The Economist, 2002). The unexpected spike in inflation and increasing energy costs caused concern over the completion of privatization in the oil industry.

In 2003, da Silva (2003-present) became President with the explicit intention of making Brazil a major world player, politically and economically (Hurrell, 2010). He aimed to realize this goal by exercising fiscal restraint, honoring contracts and private property, and continuing the preceding administration's market-oriented policies (de Onis, 2008). In 2003, Petrobras recorded a $183.3 \%$ increase in net income and operating revenues of $\$ 42.7$ billion, "the largest volume achieved in a single year by a Brazilian company" (Petrobras Annual Report, 2003). Petrobras attributes the substantial increases in net income and operating revenues to the full establishment of the competitive market in oil and the government's effective monetary policy, which saw an $18.2 \%$ appreciation of the Real with respect to the Dollar in 2003 (Petrobras Annual Report, 2003). The government's consistent economic policies and practices stimulated growth, and Brazil's GDP grew by $5.7 \%$ in 2004 (de Onis, 2008; World Development Indicators, 2010). 


\section{Attainment of Self-Sufficiency in Oil}

Petrobras continued to gain expertise in deep-water drilling and became a world leader in the development and production of biofuels (Global Agenda, 2009; The Economist, 2002). Meanwhile, the company retained near-monopoly control of the Brazilian oil industry apart from retail, including around 95\% of Brazil's oil production (Gledhill, 2008; Tollefson, 2008). In 2006, Petrobras produced an average of over 1.9 million bpd, surpassing national oil demand and attaining Brazil's longstanding vision of self-sufficiency in oil (Gledhill, 2008; Hurrell, 2010; Petrobras, 2008a). This milestone was facilitated in part by Petrobras' substantial increase in production of oil without a matching increase in domestic consumption, due to Brazil's widespread use of biofuels, as well as the government's privatization and deregulation policies (The Economist, 2007; Gledhill, 2008; Pires, 2009). From 2003 to 2007, investors' confidence in Brazil's continued economic stability and growth resulted in net inflows of foreign direct investment (FDI) of over \$34 billion, up three-fold from 2003 (World Development Indicators, 2010). During the same period, GDP rose $188 \%$, from $\$ 506.8$ billion in 2003 to $\$ 1.4$ trillion in 2007 , and inflation fell from over $14 \%$ to $4.46 \%$ (Embassy of Brazil in London, 2009). In 2007, Brazil had a $\$ 40$ billion trade surplus and international reserves of over $\$ 200$ billion, making the country a net creditor for the first time (de Onis, 2008).

\section{New Discoveries and Implications for Maintaining Self-Sufficiency in Oil}

Amidst global surges in petroleum prices and consumption in 2007, which reached record peaks of 9.7 million bpd, Brazil enjoyed self-sufficiency in oil, high production and consumption of biofuels, such as ethanol and biodiesel, and new oil discoveries (Behrens \& Glover, 2008; de Onis, 2008). Furthering Petrobras' competitive position in the international market, in 2007, Petrobras announced its discovery of oil reserves in the Tupi fields, the first of many offshore finds, estimated to hold reserves of 5 to 8 billion barrels (Petrobras Annual Report, 2008b; Lobao, 2009). The announcement caused a $26 \%$ rise in Petrobras' share price despite the company's decrease in operating profit for the year (Petrobras Annual Report, 2007; The Economist, 2007). The Tupi and subsequent offshore discoveries, labeled "pre-salt," have been estimated to double Brazil's current reserves, positioning Brazil within the top ten countries in terms of oil reserves (Lobao, 2009; Schneyer, 2007). However, Petrobras faces substantial challenges in producing oil from these pre-salt discoveries, as these are the deepest underwater discoveries in the world and extraction will need to pass through a thick layer of salt (Petrobras Annual Report, 2008b; de Onis, 2008; The Economist, 2007, 2009; Lobao, 2009). In spite of these difficulties, the company seeks to increase production to 3.6 million bpd by 2017, and with domestic consumption predicted to be around 2.6 million bpd, Petrobras expects to export approximately 1 million bpd in 2017 (Lobao, 2009).

Shortly after Petrobras' announcement of the Tupi discovery, President Lula formed a cabinet-level committee to propose legislation regarding the pre-salt oil reserves (The 
Economist, 2009; Tollefson, 2008). In addition, the ANP, in charge of bidding for concessions, withheld numerous blocks in the region around Tupi from its subsequent bidding rounds, awaiting possible government legislation regarding pre-salt production (Curtin, 2010; Global Agenda, 2009; Schneyer, 2007). In 2008, Petrobras reported a 53\% increase in net income and Brazil was the world's twelfth largest oil producer and seventh largest consumer (Petrobras Annual Report, 2008b; USEIA, 2008).

The government's reactions to the pre-salt have caused uncertainty in the capital market regarding Petrobras' future (Millard, 2010). The commission, in writing the proposals, sought to continue advancement of the oil industry in Brazil, increase benefits from oil revenue for Brazilians, and utilize the pre-salt discoveries to strengthen Brazil's export capabilities (Barrionuevo, 2010; Lobao, 2009). On August 31 ${ }^{\text {st }}, 2009$, when President Lula proposed four bills to Congress for new legislation related to the pre-salt finds, Petrobras' market value plummeted by $\$ 7$ billion that very day (The Economist, 2009; Millard, 2010; Roett, 2010). The four proposed bills would establish a new legal framework for extraction, production, and revenue allocation of oil from the pre-salt area (The Economist, 2009; Lobao, 2009; Pires, 2009). One bill proposed the adoption of production sharing contracts, displacing current concessions contracts for oil exploration and production, for future presalt areas (The Economist, 2009; Lobao, 2009; Margolis, 2009; Regalado, 2009; Roett, 2010). If passed, companies would be contracted through public bidding or directly through Petrobras, while the Brazilian government would remain the owner of all oil produced, and companies would receive percentage of revenues (Lobao, 2009). Another bill proposes that Petrobras be the designated operator, responsible for exploitation and production, in all contracts, with a minimum of 30\% share of any partnership (Lobao, 2009; Margolis, 2009; Roett, 2010). Petrobras would issue new shares, expected to be worth $\$ 30$ billion, to buy rights from the government for the equivalent of 5 billion barrels of oil from the pre-salt area (The Economist, 2009; Millard, 2010; Rabello, 2010). The third bill creates Petro-Sal, a state-owned company that would represent the government in, and have veto power over, all production sharing and related contracts (The Economist, 2009; Lobao, 2009; Roett, 2010). The final proposed bill creates a social fund to distribute Brazil's oil revenues from the pre-salt area toward poverty reduction, education, and health initiatives (Lobao, 2009; Roett, 2010; Tollefson, 2008). On March 10, 2010, the lower house of Congress passed all four proposals and an amendment, which has generated heated debate, to distribute oil revenues equally among states and municipalities, instead of the current system of revenue distribution by oil-producing states (Barrionuevo, 2010).

There is debate over the new legal framework set forth by the four proposed bills and amendment passed by the lower house of Brazil's Congress (Barrionuevo, 2010; Millard, 2010). Regarding the shift away from concessions to production-sharing contracts, critics disapprove of increased government control when market-oriented concessions contracts have worked well for the development of the oil industry (The Economist, 2009; Regalado, 2009). However, proponents of utilizing production-sharing contracts argue that the new system would provide the government with the ability to adapt to factors, such as exchange 
rate variance, in management of exploration and production (The Economist, 2009; Lobao, 2009). In addition, Brazil's state-run Energy Research Company studied the regulatory systems of the twenty countries with the largest oil reserves and determined that most countries operate with production-sharing or service contracts (The Economist, 2009; Lobao, 2009). Petrobras' possible new issue of shares would appear to dilute shareholders' stake while providing the government with more control of the company (Millard, 2010; Rabello, 2010; Regalado, 2009). Petrobras' designation as operator in all pre-salt exploitation would also decrease the role of private firms in the Brazilian oil industry (Regalado, 2009). The proposed creation of Petro-Sal is designed to increase the government's ability to monitor costs of production for oil companies; yet, the veto power given to Petro-Sal causes concern from critics that the government, instead of the market, will be determining which companies attain contracts, possibly leading to delays in development of the pre-salt area (The Economist, 2009; Lobao, 2009; Regalado, 2009; Roett, 2010). The creation of the social fund is intended to help Brazil address its domestic social inequities, but the discretion given to the government to spend what are expected to be enormous oil revenues from the pre-salt area raises questions among critics about the government's ability to control its expenditure and limit it to social programs, though the government, at least under President da Silva, has reined in expenditures and prioritized government investment on social programs (The Economist, 2009; Lobao, 2009; Roett, 2010; Tollefson, 2008).

\section{Implications of Proposed Pre-Salt Oil Legal Framework on Sustaining Self-Sufficiency}

There are multi-dimensional economic, political and historical factors contributing to the debate in Brazil about the new proposed legal framework for exploration, production, and allocation of revenues for oil in the pre-salt areas. To begin with, the upcoming presidential election in October 2010 between Jose Serra, who recently resigned as Governor of Sao Paulo and represents the leading opposition party, and Dilma Rousseff, who recently resigned as President Lula's Chief of Staff and is his chosen successor, complicates voting on the pre-salt proposals in the Senate (Dantas, 2010). As President Lula ends his second, and last by law, term in office this year (2010), this set of proposals regarding pre-salt oil represents over two years of deliberation by his administration and the committee he formed (The Economist, 2009). The successful passage of these proposed bills will leave a substantive impression with respect to his administration and is expected to affect the performance of his chosen candidate, Dilma Rousseff, in the coming presidential election. Although the proposals have passed the lower house, they must now face debate in the Senate, and it is questionable if a vote will be taken before Congress recesses in the summer. The President and his party would prefer that the bills pass the Senate as quickly as possible, before the end of the present session of Congress, but his opposition, including the opposing presidential candidate, Jose Serra, is attempting to stall voting on the bills until after the election. These internal factors, the debate over the pre-salt legislation coupled with election politics, are causing great uncertainty in the external financial market, as 
international investors question the expected stability of Brazil's monetary and fiscal policy and the predicted affect of the legislation on Petrobras' future.

In the seven months after the announcement in November 2007 of its Tupi field discovery, Petrobras' share price rose 50\% to an all-time high of over $\$ 72$ per share (Palmeri, 2008). In 2008, it became the second largest company in the Americas, after ExxonMobil, by stock market value, with market capitalization of $\$ 310$ billion (Palmeri, 2008). Since then, however, signals from the Brazilian government, including the removal of numerous blocks in the pre-salt area from bidding and the proposals for a new legal framework, have caused relative weakness in the stock price (Millard, 2010). This may reflect the uncertainty regarding the passage of legislation related to the pre-salt area and investor fears of increased government control in the oil sector (Millard, 2010). Part of the proposed legislation entails a new issue of shares, which could range from $\$ 30$ to $\$ 50$ billion by Petrobras in exchange for rights to as much as 5 billion barrels of oil in the pre-salt area (The Economist, 2009; Regalado, 2009). Petrobras' share offer, if approved by Congress, should attract substantial investment as it would coincide with the passage of the proposed legislation, which would eliminate most of the uncertainty the market is currently experiencing (Millard, 2010). Yet, investors may remain skeptical due to a set of other factors presented by the proposed legislation, including increased government control and monitoring of the oil industry, the end of a transparent bidding and concessions contract system, and the possibility of Petrobras' decreased autonomy. If Petrobras cannot reassure investors in its future consistent operational success, the company may face difficulty in achieving a fruitful share offering, which could prevent its attainment of the rights to 5 billion barrels in the pre-salt area from the government.

Since the beginning of Brazil's privatization of the oil industry in 1995, Petrobras has continued to thrive in the newly competitive environment. Brazil has also benefited: the country is now self-sufficient in oil and can look forward to becoming a major oil exporter, furthering the country's historical objective of self-determination along with President Lula's, and the Brazilian people's, aspirations for the rise of Brazil as a leader in global politics (Gledhill, 2008; Hurrell, 2010; Petrobras, 2008a). Brazil's privatization and deregulation policies appear not to have resulted in negative side effects for the country's exploration, production, or refining capability to meet domestic demand. Yet, the government's proposed legislation seeks to increase regulation with respect to the pre-salt areas, currently estimated to hold around 30 billion barrels of reserves of light crude oil (Lobao, 2009). The proposed establishment of Petro-Sal to take charge of managing and approving contracts in the pre-salt areas, and a social fund, to allocate the future revenues generated, suggests that the current government is seeking increased involvement in developing the new pre-salt areas, generation of more federal and state income than what it receives presently, and additional investment in social programs for Brazilians (The Economist, 2009; Lobao, 2009).

In proposing to increase government involvement, the Brazilian government may be acknowledging expected challenges to developing the pre-salt region for successful 
exploration and production. Issues related to the oil's extreme depth-the deposits are the deepest ever discovered - and its position under a thick, shifting layer of salt have caused concern over the viability of profitable production from the pre-salt areas (The Economist, 2009; Petrobras Annual Report, 2008b; Pires, 2009). The fire on, and subsequent sinking of, an exploration drill in the Gulf of Mexico on April 21, 2010, with British Petroleum (BP) as lease operator, has caused political reconsideration of deep-water drilling, raised questions regarding technical limitations of drilling and extraction technology, and has already produced disastrous economic and environmental impacts in the region (Condon, 2010). In March of 2010, BP bought assets in several deep-water blocks in Brazil from Devon Energy, including some in the pre-salt region (BP, 2010). However, the Brazilian government and Petrobras, considered to be one of the top companies in the world with respect to deep-water drilling expertise, would be expected, especially in light of the recent BP incident, to take extra safety precautions in oil production from the pre-salt areas.

One of the government's goals of proposing the new framework may be to ensure exploration and production, even if there is a lack of private interest to do so, if extraction costs become higher than oil prices. In creating Petrobras in 1953, the government had controlled and funded the beginnings of the oil industry in Brazil because private efforts had been insufficient and production was only $3 \%$ of national consumption (Petrobras, 2008a). The government's current legislation, though it would not forbid private participation in the pre-salt area, reflects the government's apprehension that full competition in the sector is optimal to Brazil's long-term plans to become a key exporter of oil. These concerns may be justified by the lack of knowledge about, and technological experience in, efficient production from the pre-salt region. However, Petrobras is a world leader in deep-water exploration and production expertise, and even if Petrobras were unable to meet the technological challenges, other private oil companies would likely attempt to do so. In addition, private, mostly foreign, oil companies have shown substantial interest in the Brazilian oil industry, including the pre-salt region, as evidenced by the competition in the bidding rounds for concessions contracts held by the ANP (ANP, 1999). Private interests competing in the Brazilian oil industry can be expected to develop the oil in the pre-salt regions under the current system.

There may, however, be other implicit factors contributing to the government's proposed legislation. One of the precursors to the creation of a state monopoly in oil in 1953 was "the oil is ours" national campaign (Smith, 1972; Wirth, 1970). This campaign was founded on the idea that the natural resources of Brazil, specifically oil in this case, should belong to the people. In particular, this placed an emphasis on oil revenues being used for domestic development and blocking foreign investment and participation (Smith, 1972). This sentiment of limiting benefits from natural resources to Brazilians may be recurring as an underlying theme in the proposed legislation. Petro-Sal, if created, would be wholly owned by the government, represent the government in all contract negotiations, and have veto power over the contracts (The Economist, 2009; Lobao, 2009; Roett, 2010). The government, through Petro-Sal, could potentially limit foreign participation in the pre-salt 
Guan: Understanding Brazil's Oil Industry: Policy Dynamics and Self-Sufficiency

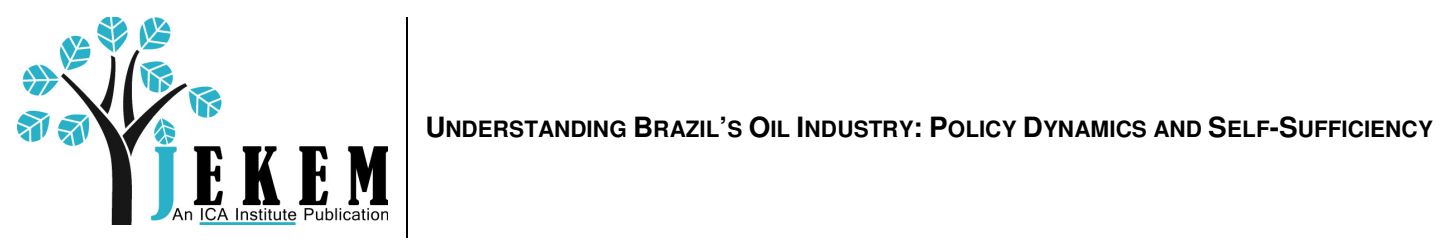

region if production did not meet its expectations or national sentiment grew again to echo 1947 levels.

Another aspect of the proposed legislation is a production-sharing system for pre-salt oil, a clear deviation from the concessions contracts currently in place, in which half of all oil revenues would go to the government (de Noronha Goyos, 2003; The Economist, 2009; Lobao, 2009; Regalado, 2009; Roett, 2010). This would increase revenues, including royalties and taxes, the government currently receives from Petrobras. The need for this prospective increase is not immediately evident as the government, since President Lula's inauguration in 2003, has increased FDI, maintained steady GDP growth, and became a net creditor. Thus, the government does not seem to be in need of additional income as it has maintained budget surpluses for over six years (Maxwell, 2010; World Development Indicators, 2010). However, budget surpluses have been a priority since Lula took office in 2003 because of the positive signal it sent to the international financial market that Brazil was dedicated to reducing its debt and to ensure financial reserves in case of crises (Maxwell, 2010). Due to this commitment to budget surpluses, the government has had to limit its spending, particularly on investment in its future human capital through education. With more oil revenues from the pre-salt regions, the government would be able to enlarge its current investment, thus advancing toward long-term national development and selfreliance.

\section{Conclusion}

Since the 1940s, Brazil has, under various forms of governmental leadership, continually advanced toward its vision of self-sufficiency in oil. Its realization of that vision in 2006 has reinforced the belief in the capabilities of the Brazilian people and their government, within, and at times, despite, their historical context (Palmeri, 2008). When government regulation of the oil industry did not further the progression toward self-sufficiency, the people vocalized their disapproval through protests and votes, and the government had a pattern of self-adjustment to re-adhere to the vision. Since 2006, Brazil's new vision is to sustain selfsufficiency while becoming a leading exporter of oil. Thus, the proposals regarding oil in the pre-salt region currently before the Senate represent either an effort to advance this new vision or a divergence from it, which will result in failure to pass the Senate or eventual readjustment by future governments. Historically, the Brazilian Congress has a tendency to pass legislation regarding the oil industry presented by the President, as in 1953, 1975, 1995, and 1997, though bills may undergo changes and amendments. The current legislative framework has already been modified by one amendment, regarding distribution of oil revenues between states and municipalities, and passed the lower house by a vast majority. From historical inference and barring any significant changes, the Senate should approve the President's proposed legislative framework; however, the timing of a vote is questionable. 
With the approaching presidential elections, the opposing political forces are attempting to either speed up voting on the legislation, as is the case for supporters of President Lula, or delay it until after the election, as are the supporters of Jose Serra and the general opposition. Though the timing of the vote is relatively insubstantial in the long-run with respect to the oil industry, the passage, or delay, of the legislation may affect the outcome of the presidential elections, which will impact the oil industry and the new legal framework. The outcome of the elections will also affect investors' perception of Brazil along with their interest in Petrobras. Petrobras' shares have been relatively weak for over a year, partly due to uncertainty surrounding the new legal framework for the pre-salt area and its prospective effects on Petrobras' performance. No matter the outcome of the Senate's vote, the company's shares should revive once the uncertainty is removed from the market (Millard, 2010). If the legislation passes and Petrobras issues new shares, the company should not face challenges in raising the capital it needs, as its history of production growth, dominant presence in an emerging market, and long-term investments should ensure investor confidence in the company.

The proposed legal framework would increase the government's role in regulating and controlling the pre-salt segment of the oil industry in Brazil while raising its revenue. The Brazilian government has historically protected its infant industries through monopoly powers or government ownership, or both. Although the Brazilian oil industry is already established, the risks and challenges associated with the pre-salt sector of the oil industry may prompt government protection. The success of Petrobras may even enhance the prospect of Petro-Sal for the government. However, government deregulation and opening of the oil industry contributed to the success of Petrobras in the past decade or so and helped the country reach self-sufficiency. Through these proposals the government has implied that it foresees risks associated with allowing private competition in the pre-salt oil sector under the current system. In the case that the legislation passes, Petro-Sal may not exercise its veto power and allocate production-sharing contracts to private companies in a competitive manner. Even if Petro-Sal uses its veto power against private or foreign oil companies, the government may choose to deregulate the sector after initial production has affirmed progress toward the government's goal to place Brazil among the top oil exporters in the world.

Lastly, with respect to the increased share the government would receive of oil revenues, the Brazilian government has a long history of prioritizing accelerated growth and development instead of economic stability. Since Cardoso's Real Plan in 1994 and Fiscal Responsibility Law in 2000, Brazil has given more attention to its monetary and fiscal policy. President Lula's maintenance of a budget surplus throughout his two administrations has reassured the financial community while allowing him to prioritize his budget allocations. With an increase in government revenue from oil production in the pre-salt area, the government would have more to invest in its economic and social programs, giving it greater capital in the long-run. However, these revenues are tied to the realization of profitable production from the pre-salt region, which may be hindered by government 
control given to Petro-Sal. Thus, if the new legal framework passes the Senate, the government will keep a vigilant watch over the exploration and production efforts in the new system in comparison with the current concessions system. However, should the expected revenues not materialize, the government will have a strong incentive to change the regulatory framework back to the current system as a means to continue the nation's envisioned economic development trajectory.

\section{References}

Agência Nacional do Petróleo (ANP) (1999). Retrieved 15 March 2010, from HYPERLINK "http://www.anp.gov.br/brasi1\%2Drounds/round1/HTML/Winning_en.htm" http://www.anp.gov.br/brasil\%2Drounds/round1/HTML/Winning_en.htm

Barrionuevo, A. (2010, March 17). Rio de Janeiro is in Fight Over Brazil's Oil Riches. New York Times. Retrieved 8 April 2010, from http://www.nytimes.com/2010/03/18/world/americas/18brazil.html

Bello, J.M. (1966). A History of Modern Brazil 1889-1964. Stanford, Stanford University Press.

Bethell, L. (2008). Politics in Brazil Under Vargas, 1930-1945. In Leslie Bethell (Ed.), Brazil Since 1930. Cambridge University Press. Cambridge Histories Online. Cambridge University Press. Retrieved 27 March 2010, from http://histories.cambridge.org/extract?id=chol9780521395243_CHOL9780521395243A $\underline{002}$

BP (British Petroleum) (2010, March 11). BP Enters Deepwater Brazil and Strengthens Core Portfolio. Retrieved 6 July 2010 from http://www.bp.com/genericarticle.do?categoryId=2012968\&contentId=7060559

Condon, S. (2010, April 30). Axelrod: No New Drilling Until Cause of Oil Spill Determined. CBS News. Retrieved 5 July 2010 from http://www.cbsnews.com/8301$\underline{\text { 503544_162-20003846-503544.html }}$

Country Analysis Briefs: Brazil Energy Data, Statistics and Analysis - Oil, Gas, Electricity, Coal (2009, Sep.). U.S. Energy Information Administration (EIA). Retrieved 24 March 2010, from http://www.eia.doe.gov/emeu/cabs/Brazil/Oil.html

Curtin, M. (2010, March 12). BP Sambas into Brazil. The Wall Street Journal.

Dantas, I. (2010, April 10). Brazil's Serra to Run for President, Vows Investment. BusinessWeek. Retrieved 11 April 2010 from http://www.businessweek.com/news/2010-04-10/brazil-s-serra-says-he-will-run-forpresident-vows-investment.html 
de Albuquerque Barreto, C. (1998, June 30). Law 9478 of August $6^{\text {th }} 1997$ : The New Brazilian Oil Regulation. The Centre for Energy, Petroleum and Mineral Law and Policy. Retrieved 20 March 2010, from http://www.dundee.ac.uk/cepmlp/journal/html/old_brazil.html

de Noronha Goyos, Jr., D. et al. (2003). Legal Guide: Business in Brazil. $6^{\text {th }}$ ed. Brazil: Observador Legal Editora Ltda.

de Onis, J. (2008). Brazil's Big Moment. Foreign Affairs, 87(6), 110-122. Retrieved 10 April 2010, from ABI/INFORM Global. (Document ID: 1581257991).

de Sa Ribeiro, M.R. (2001). The New Oil and Gas Industry in Brazil: An Overview of Main Legal Aspects. Texas International Law Journal. 13(1), 141-167.

The Economist (2002, May 18). Business: The price of freedom; Petrobras. 363 (8273), 88.

The Economist (2007, Nov. 17). All This and Oil Too. 385(8555), 43-44.

The Economist (2009, Sep. 5). The Americas: Preparing to spend a "millionaire ticket" from offshore; Brazil's oil policy. 392(8647), 42.

Foreign Affairs (2009). Getting Energetic. 88(1), 7. Retrieved 20 March 2010, from Academic Search Complete database.

Furtado, A. T. (2002) Institutional Change and Innovation in the Brazilian Oil Industry. Technology Policy Briefs 1(4), 10-12. Retrieved 18 March 2010, from

Gledhill, J. (2008). The people's oil': Nationalism, globalization, and the possibility of another country in Brazil, Mexico, and Venezuela. Focaal: European Journal of Anthropology 52, 57-74.

Global Agenda (2009, March 21). The Next Oil Giant? 9. Retrieved 21 March 2010, from Academic Search Complete.

Gruben, W. C, Kiser, S. (1999). Brazil: The First Financial Crisis of 1999. Federal Reserve Bank of Dallas, 13-14. Retrieved 5 April 2010, from http://www.dallasfed.org/research/swe/1999/swe9902c.pdf

Hakim, P. (2002). Two Ways to Go Global. Foreign Affairs, 81(1), 148-162. Retrieved 10 April 2010, from ABI/INFORM Global. (Document ID: 98465704)

Hudson, R. (Ed.) (1997). Brazil: A Country Study. Washington, GPO for the Library of Congress. Retrieved 10 March 2010, from http://countrystudies.us/brazil/

Hurrell, A. (2010). Brazil and the New Global Order. Current History 109(724), 60-66.

Lobão, E. (2009, Nov. 24) Proposal for Pre-Salt Legal Framework [PowerPoint slides]. Retrieved 16 March 2010, from http://www.brazilcham.com/default.asp?id=262\&c030_ui=desc\&c030_id=424\&pn=1\& c030 ret $=1 \& \mathrm{c} 030$ from $=$ listall $\& \mathrm{c} 030$ is $=0 \& \mathrm{c} 030$ catid $=44$ 
Margolis, M. (2009, October 12). Brazil Battles the 'Oil Curse.'” Newsweek.

Millard, P. (2010, February 24). Petrobras Lures Armada as Brazil Oil Bill Advances. BusinessWeek.

Oil \& Gas Journal (1991). Petrobras Role in Brazil's Economy Disputed. 89(2), 47-51.

Petrobras (2008a). Retrieved 11 March 2010, from http://www2.petrobras.com.br/ingles/index.asp

Petrobras (2008b). Annual Report 2008. Retrieved 4 April 2010, http://www2.petrobras.com.br/ri/ing/ConhecaPetrobras/RelatorioAnual/pdf/RelatorioAn ual_2008_ing.pdf

Pires, A. and Schechtman, R. (2009). Analysis of the Power Industry in Brazil. Brazil \& Sweden Norway 21. Retrieved 10 March 2010, from http://www.swedcham.com.br/pdf/B\&SN_JUN_2009LOW.pdf

Raine, P. (1974). Brazil: Awakening Giant. Washington, D.C.: Public Affairs Press.

Randall, L. (1993). The Political Economy of Brazilian Oil. Westport, Praeger.

Regalado, A. (2009, August 6). World News: Brazil to Control Recent Big Oil Find. Wall Street Journal (Eastern Edition), p. A.8. Retrieved 30 March 2010, from ABI/INFORM Global. (Document ID: 1819222031)

Roett, R. (2010). How Reform has Powered Brazil's Rise. Current History 109(724), 4752.

Schneyer, J. (2007, Nov. 20). Brazil, the New Oil Superpower.” BusinessWeek Online.

Smith, P.S. (1972). Petrobras: The politicizing of a state company, 1953-1964. Business History Review, 46(2), 182-201.

Stevenson, A. (Ed.) (2007). Shorter Oxford English Dictionary $\left(6^{\text {th }}\right.$ ed., Vols. 1-2). Oxford, England: Oxford University Press.

Surrey, J. (1987, Feb.). Petroleum Development in Brazil: The Strategic Role of a National Oil Company. Energy Policy 15(1), 7-21.

Tollefson, J. (2008, September 24). Brazil Braced for Unexpected Oil Wealth. Nature 455, 438-439. Retrieved 21 March 2010, from http://www.nature.com.www.library.gatech.edu:2048/news/2008/080924/full/455438b. $\underline{\mathrm{html}}$

Wilkins, M. (1974). Multinational Oil Companies in South America in the 1920s: Argentina, Bolivia, Brazil, Chile, Colombia, Ecuador, and Peru. Business History Review 48(3), 414-446.

Wirth, J. (1970). The Politics of Brazilian Development 1930-1954. Stanford, Stanford University Press. 
World Development Indicators (2010). The World Bank. Retrieved 28 March 2010, from http://datafinder.worldbank.org/

World Development Report (1978). The World Bank. Retrieved 30 March 2010, from http://wwwwds.worldbank.org/external/default/WDSContentServer/WDSP/IB/2000/12/13/000178 $\underline{\text { 830_98101903334595/Rendered/PDF/multi_page.pdf }}$

Zylbersztajn, D. (1998, Dec. 18) Press Release. Agencia Nacional do Petróleo, Gás Natural e Biocombustiveis. Retrieved 14 March 2010, from http://www.anp.gov.br/brasil\%2Drounds/round1/HTML/Press en.htm 

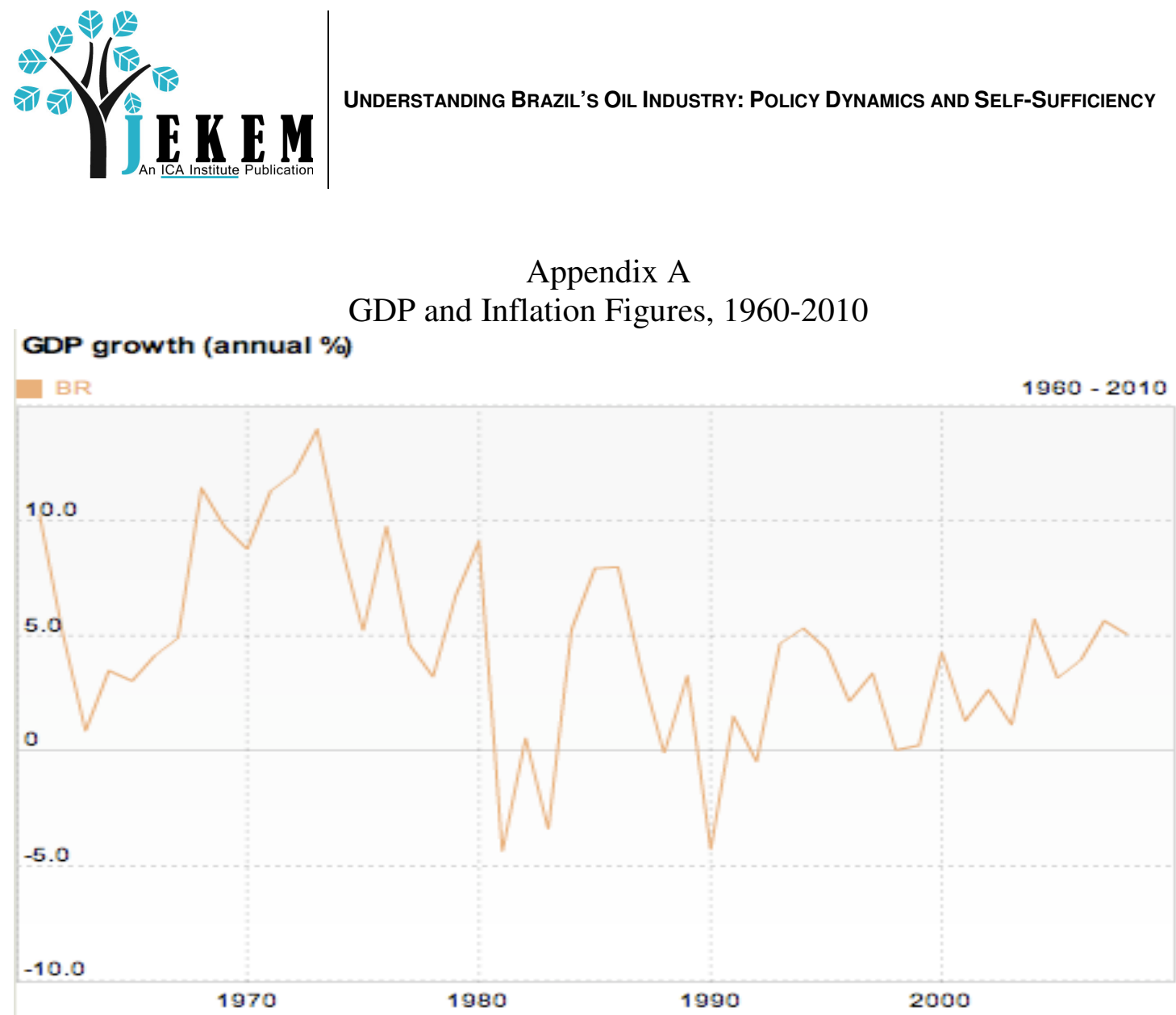

Figure 1. Source: World Development Indicators, 2010.

Inflation, GDP deflator (annual \%)

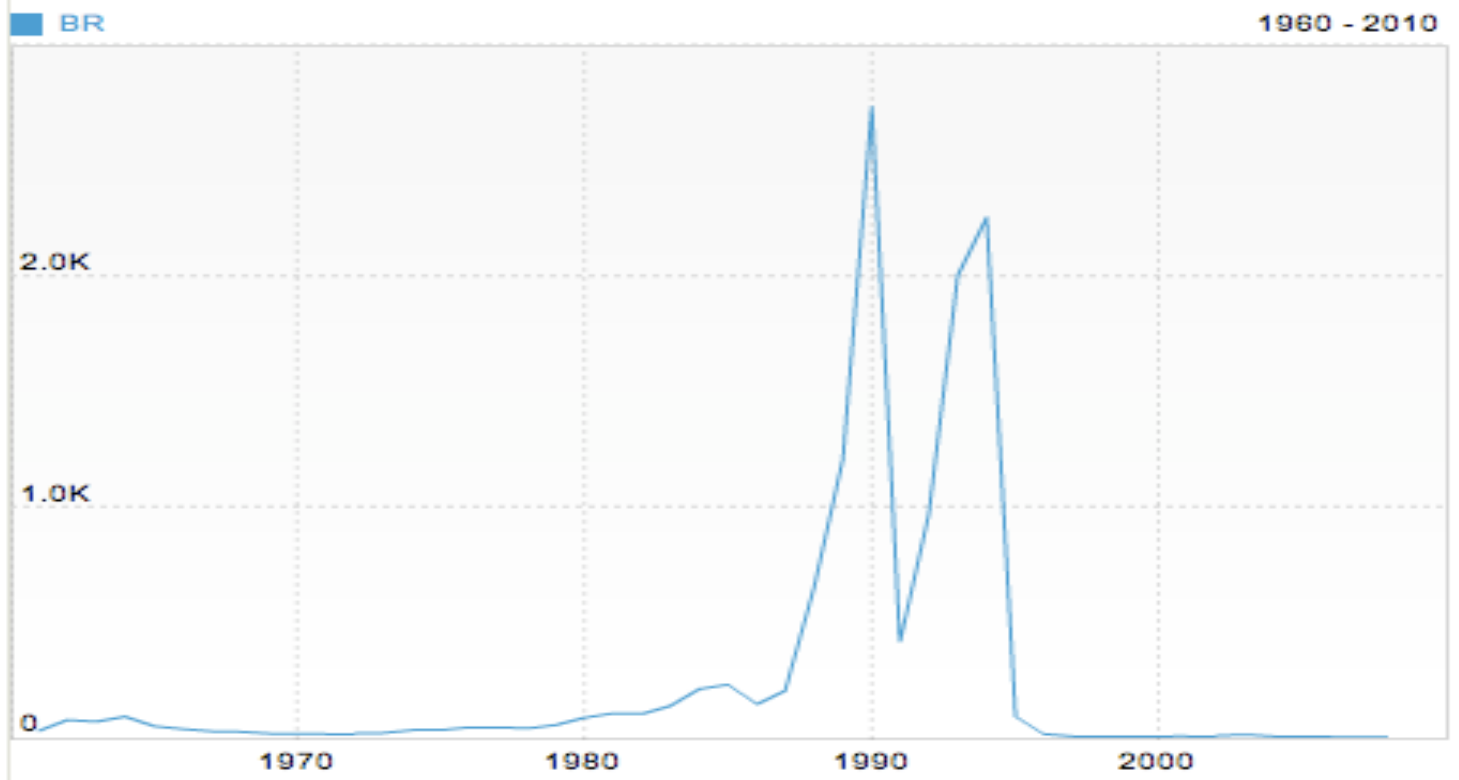

Figure 2. Source: World Development Indicators, 2010. 


\section{Appendix B}

Petroleum Production and Consumption Figures, 1954-2008

\section{Petrobras Annual Crude Oil Production}

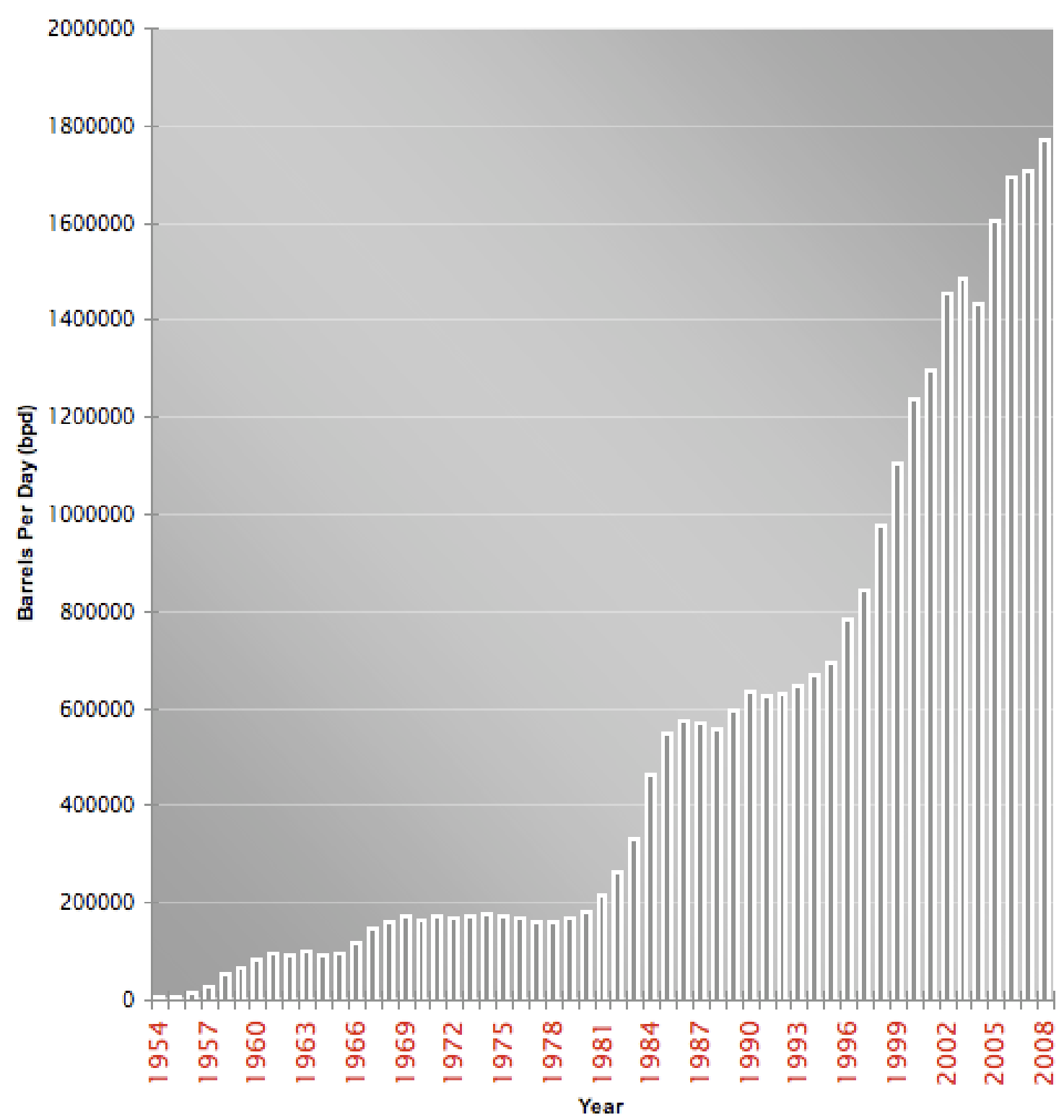

Figure 1. Source: Petrobras, 2008a. Configured by author. 


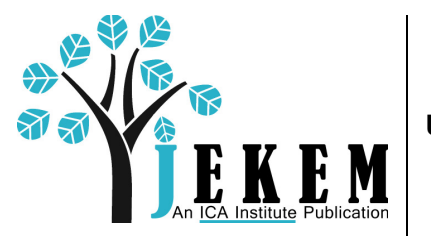

Understanding Brazil's OIL Industry: Policy Dynamics and Self-Sufficiency

$\%$ of Brazil's Oil Consumption Met by Domestic Production

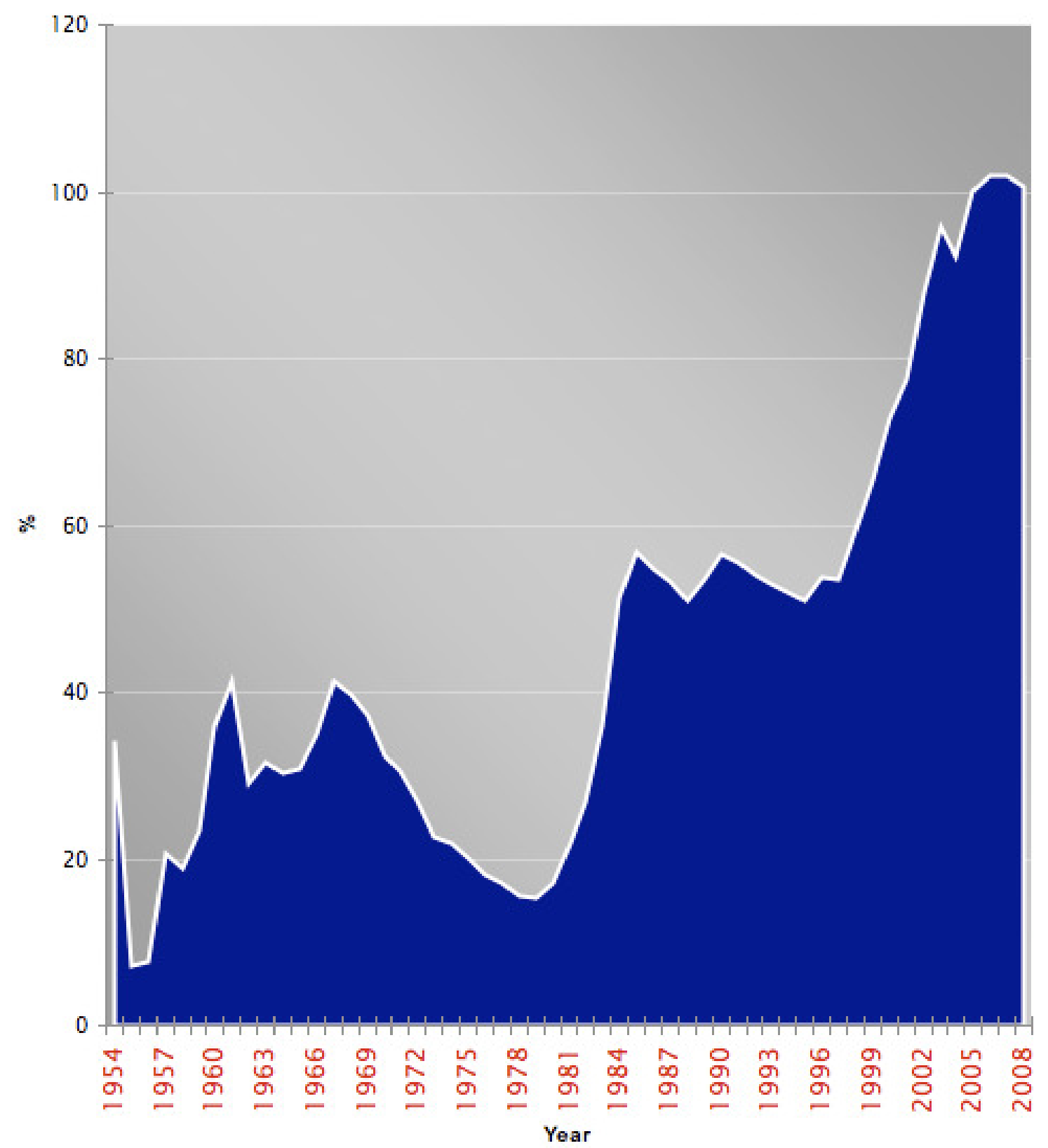

Figure 2. Sources: Ministério de Minas e Energia, 2010; Petrobras, 2008; Randall, 1993. Data compiled and configured by author. 